\title{
DESTAQUES
}

\section{SIMPOSIO SOBRE $O$ PROJETO DE CÓDIGO CIVIL PROMOVIDO PELA ASSOCIAÇÃO dOS MAGISTRADOS BRASILEIROS (*)}

\author{
RELATÓRIO GERAL
}

\section{INTRODUÇÃO}

A Associação dos Magistrados Brasileiros, no intuito de colaborar para o aprimoramento do Direito, deliberou realizar um Simpósio sobre o Projeto de Código Civil, ora em tramitação no Congresso Nacional, assunto momentoso e de grande interesse não somente para os juristas, em geral, mas para a população brasileira, em toda a sua amplitude.

Atenderam gentilmente ao convite da Associação renomados membros da Comissão Elaboradora e Revisora do Anteprojeto de Código Civil, atual Projeto, a começar pelo insigne Professor MIGUEL REALE, os quais pronunciaram conferências lapidares em que, a par das diretrizes gerais do alentado trabalho, teceram considerações precisas a respeito de cada uma das partes que thes coube elaborar.

O Professor CAIO MARIO DA SILVA PEREIRA, conquanto não tenha sido membro daquela Comissão, trouxe ao Simpósio, no âmbito do Direito das Obrigações, a palavra brilhante, ensejada pela sua indiscutível cultura jurídica.

Figuras expressivas da Magistratura e do Magistério pátrios, vindas de todos os recantos do Brasil, emprestaram ao Simpósio os subsídios de seus conhecimentos e de sua experiência, na complexa e básica repartição da Ciência Jurídica, que é o Direito Civil.

Com a presença de autoridades e de cultores preeminentes do Direito, o Desembargador LUIS HENRIQUE STEELE FILHO, Presidente da Associação dos Magistrados Brasileiros, inaugurou o Simpósio, às 13 horas do dia $1 .^{\circ}$ de dezembro de 1975.

(•) Realizado na cidade do Rio de Janeiro, no período de 1.0 a 5 de dezembro de 1975. 
Pronunciou, então, S. Ex. ${ }^{a}$ uma alocução, em que rememorou os trabalhos legislativos e os subsídios de juristas de escol, conducentes à elabloração do Código Civil, - passando, após, a sailentar a inadequação do diploma em face das realidades sociais hodiernas.

Por fim, teceu comentários à estrutura e ao conteúdo do atual Projeto de Código Civil, referindo-se encomiasticamente à douta Comissão Elaboradora e Revisora.

\section{CONSIDERAÇÕES GERAIS}

O Projeto de Lei n. ${ }^{\circ}$ 634, de 1975, despertou a consciência juridica nacional.

Já o Anteprojeto de Código Civil desencadeara um movimento de críticas dirigidas não só às suas diretivas, uma vez que há os numerosos partidários de uma simples modernização do Códig̣o $\mathrm{Ci}$ vil em vigor, para adaptá-lo à realidade sócio-econômica brasileira, como também ao seu conteúdo, frisando muitos a inoportunidade ou a deficiência de diversos dispositivos, e ainda, até, à linguagem empregada.

Habituados estamos a uma codificação de 1807 artigos apenas, claros, escorreitos, precisos, de forma acrisolada na famosa polêmica entre RUI e ERNESTO CARNEIRO RIBEIRO.

Portanto, a reação dos juristas ao Projeto é susceptível de compreensão.

Os ilustrados membros da Comissão Elaboradora e Revisora, se por outro lado não são infensos a críticas que visem a alterações por um lado, com denodo, aduzem defesa ao seu trabalho, por outro lado não são intensos a críticas que visem a alterações eficazes.

O Professor MIGUEL REALE, mesmo, asseverou que apresentará à Comissão Especial dezessete emendas ao Projeto.

Logo, eles admitem a tangibilidade de sua obra.

O Projeto é mutável por excelência e a prova desta asserção está no avultado número de emendas apresentadas, que ultrapassam um milhar.

Vários pontos são susceptíveis de debate e, apenas, para exemplificar, vale referir a inclusão da chamada "Atividade Negocial", constitutiva que é do Livro II da Parte Especial.

Busca-se o corpo de normas que mais se afeiçoe à situação 
atual do povo brasileiro, atendido seu desenvolvimento social, econômico e cultural.

A obra de aperfeiçoamento é válida e a ela não poderia omitirse a Associação dos Magistrados Brasileiros.

Aqueles que indefessamente aplicam, muitas vezes em condições adversas, o direito ao caso concreto, em toda a extensão de nosso território, estão indiscutivelmente legitimados a trazer sua coopração à tarefa ingente.

Os Magistrados, que atuam nas várias regiões geográficas de um País de dimensões continentais, como é o nosso, podem estudar e criticar o Projeto, à luz das peculieridades locais, para que efetivamente o novo Código Civil se aplique sem distorções e não seja um estatuto, apenas, do homem das grandes metrópoles.

Conjuntamente com os Magistrados, os Professores especialmente convidados também prodigalizaram, nas diferentes Comissões, os frutos opimos de seu cabedal científico e de seu tirocínio proficiente.

Em assim sendo, a Associação dos Magistrados Brasileiros acredita haver propiciado uma reunião de estudiosos, para o debate sério do Projeto, em suas diversas e importante facetas.

\section{DOS TRABALHOS}

Foram os trabalhos divididos em duas partes distintas: a expositiva e a de crítica e proposições.

A primeira se cingiu à explanação, em forma de conferência, isenta de debate, da matéria constante de cada parte do Projeto.

Compreendeu a segunda o estudo, em seis comissões, de temas previamente apresentados, não sendo, outrossim, vedada a adução momentânea de assuntos que se traduzissem em proposições.

\section{a) - Das conferências}

Dissertou inicialmente o Professor MIGUEL REA.LE sobre "Diretrizes Gerais do Projeto do Código Civil", justificando a forma de elaboração e defendendo a sistemática das matérias disciplinadas.

A seguir, na mesma sessão, usou da palavra o Ministro JOSE CARLOS MOREIRA ALVES, discorrendo sobre a Parte Geral.

Apresentou ele, com sua inegável erudição, a justificação da mantença da Parte Geral, apesar das críticas que se levantam na doutrina. 
Finalizando a primeira sessão, o Professor SYLVIO MARCONDES fez sua conferência a respeito da "Atividades Negocial", aduzindo, também em alto nível, os fundamentos da inclusão do referido livro no Projeto.

O Desembargador EBERT CHAMOUN, enfermo, não pode pronunciar sua explanação.

Na subsequente sessão, ouviu-se o Professor CAIO MARIO DA SILVA PEREIRA, sobre o Direito das Obrigações, oportunidade em que efetuou ele algumas críticas ao livro em referência.

Em seguida, o Professor CLÓVIS DO COUTO E SILVA se ocupou do Direito de Família.

Encerrando o ciclo de conferências, falou o Professor TORQUATO CASTRO sobre o Direito das Sucessões.

De um modo geral, em face da limitação do tempo, os conferencistas cuidaram dos pontos essenciais de cada livro, ressaltando as alterações introduzidas ao direito positivo em vigor e, quando fosse o caso, apoiando-as com subsídios doutrinários.

Assim, revelou-se proveitosa a primeira fase do Simpósio, em que foram ouvidas, inclusive, as abalizadas vozes dos membros da Comissão Elaboradora e Revisora, capazes, indubitavelmente, de esclarecer, de modo profícuo, as razões que os levaram ao estabelecimento das novas normas, muitas das quais alvo de acerba crítica.

\section{b) - Das Comissões}

O estudo crítico do Projeto e a incumbência de apresentar proposições couberam a seis Comissões, cada uma das quais correspondendo a um livro.

Ficaram assim constituídas estas Comissões:

\section{9) - Parte Geral}

Presidente: Ministro Renato Machado (T.S. Trabalho)

Relator: Juiz Dr. Geraldo de Arruda Guerreiro

Des. José Maria de Queiroz (T.J. Ceará)

Des. José Pessoa de Oliveira Cavalcanti (T.J. Pernambuco)

Prof. Hamilton Xavier (U.F. Fluminense)

\section{2. $\left.{ }^{a}\right)$ - Obrigações}

Presidente: Juiz Tomaz Gomes Campelo (Assoc. Piauí)

Relator: Juiz Narcizo Arlindo Teixeira Pinto

Juiz Ilmar Nascimento Galvão (Acre T.J.) 
Prof. Francisco José Lutzemberger (Fac. Estácio de Sá)

Prof. Paulo Cezar Chaves de Aragão (Fac. Gama Filho)

\section{9) - Atividade Negocial}

Presidente - Des. Ary Florêncio Guimarães (Assoc. Paraná)

Relator: Des. J.C. Sampaio de Lacerda

Des. Hamilton de Moraes e Barros (T. J. Rio de Janeiro)

Des. Paulo Barbosa Lessa (T.J. Rio Grande do Sul)

Des. Serapião de Aguiar Torres (T. J. Sergipe)

Juiz Joaquim Antonio de Vizeu Penalva Santos (T.A. Rio de Janeiro).

\section{4. ${ }^{a)}$ - Direito das Coisas}

Presidente: Des. Agnano Monteiro Lopes (T.J. Pará)

Relator: Des. Basileu Ribeiro Filho

Des. Homero Mafra (Assoc. Espírito Santo)

Des. Geraldo Gama Salles (Assoc. Santa Catarina)

Juiz José Domingos Moledo Sartori (II. T.A. Rio de Janeiro)

\section{5. - Direito de Família}

Presidente: Des. João de Oliveira e Silva (T.J. Alagoas)

Relator: Juiz Onurb Couto Bruno

Des. Domingos Sávio Brandão Lima (T.J. Mato Grosso)

Des. Bruno Afonso de André (Assoc. São Paulo)

Juiz Manuel Cândido Filho (Assoc. Sergipe)

Juiza Maria Rita Soares de Andrade (Assoc. Brasília)

Prof. Simão Isaac Benjó (U.E.R. J. Rio de Janeiro)

Juiz Danilo Antônio Barreto Accioly (Assoc. Alagoas)

Juiz Sebastião Rios Corrêa (Assoc. D. Federal)

\section{6. $\left.{ }^{9}\right)$ - Direito das Sucessões}

Presidente: Des. Aderbal Gonçalves (Bahia)

Relator: Juiz Carlos Gualda

Des. Costa Manso (São Paulo)

Des. Ribeiro do Valle (Minas Gerais)

Juiz Benito Augusto Tiezzi (Rio de Janeiro)

Merece destaque o comparecimento do Desembargador EBERT CHAMOUN à 3. ${ }^{a}$ Comissão (Direito das Coisas) e do Professor TORQUATO CASTRO à 6. Comissão (Direito das Sucessões).

Ambos fizeram uso da palavra, contribuindo eficientemente para o desenvolvimento dos 1rabalhos. 


\section{DAS PROPOSIÇÕES}

Foram discutidas e aprovadas as seguintes proposições:

\section{Comissão}

(Parte Geral)

\section{1.` Proposição}

Excluir do art. 24, $\S 2 .^{\circ}$, relativo à curadoria dos bens do ausente, a preferência em razão do sexo.

\section{Justificativa}

Não é admissível, no estágio atual do Direito, a distinção pretendida.

\section{R.a Proposição}

Definir, com maior precisão quantitativa, o conceito de desproporcionalidade caracterizador de lesão (art. 155).

\section{Justificativa}

Visa-se, com a sugestão, a evitar principalmente dificuldade no aplicação da norma.

\section{3.` Proposição}

Alterar o art. 28, relativo à conservação do valor da herança, para permitir a conversão também em títulos de empresas públicas da União.

\section{Justificativa}

Objetiva-se maior amplitude no prudente arbítrio do juiz.

\section{4.` Proposição}

Incluir a fiança bancária dentre as garantias do herdeiro para se imitir na posse dos bens do ausente (art. 29).

\section{Justificativa}

A fiança bancária é de correntia prática e enseịa ao herdeiro outra opção.

\section{5." Proposiçāo}

Incluir no art. $7 .^{\circ}$, inc. $2 .^{\circ}$, relativo à morte presumida, a hipótes e de desaparecimento do não combatentes, é comum no caso 


\section{Justificativa}

O desaparecimento de civis, não combatentes, é comum no caso de guerra e o Código não há de distanciar-se da realidade.

\section{6.' Proposição}

Alterar a redação do art. 124, para maior clareza.

\section{Justificativa}

Intenta-se que a relativa obscuridade do texto não venha a causar dúvida, quando de sua aplicação.

\section{7.a Proposição}

Alterar o art. 130, relativo a prazos, para manter, integralmente, a disciplina do art. 184, § $2 .^{\circ}$, do Código de Processo Civil, quanto ao termo inicial coincidente com feriado.

\section{Justificativa}

Aspira-se à concordância da norma de direito material com a de direito processual pertinente.

\section{8." Proposição}

Dar melhor definição quantitativa ao dano considerável resultante da coação (art. 149).

\section{Justificativa}

Tem-se o intento de facilitar a aplicação da norma.

\section{9." Proposição}

Considerar a simulação (art. 165) motivo de anulabilidade, não de nulidade.

\section{Justificativa}

Preferiu-se preservar o tratamento da matéria feito pelo Código vigente, por parecer mais consentâneo com o denominado vício social, constituído pela simulação.

\section{0.' Proposição}

Incluir no art. 212 o dolo como motivo de revogação da confissão, em consonância com o Código de Processo Civil.

\section{Jusificativa}

Busca-se, de novo, a concordância entre disposiçōes análogas dos dois Códigos. 


\section{'11." Proposição}

Excluir, no art. 213, relativo à escritura púbilca, a menção a prova plena.

\section{Justificativa} prova.

A doutrina moderna exclui os graus apriorísticos da eficácia da

\section{2." Proposição}

Entendeu a Comissão de restringir a prova equipolente à dos originais.

\section{3.` Proposição}

Alterar os arts. 225, 226 e 227, relativos às provas, para manter a sistemática dos artigos 401, 402, 405 e 406 do Código de Processo Civil.

\section{Justificativa}

Ainda aqui o tentame é de tratamento idêntico à matéria que compartilha de ambos os Códigos.

\section{4." Proposição}

Acrescentar o seguinte parágrafo único ao art. 184: "Salvo se a prova ou as circunstâncias indicarem o contrário, presumir-se-á a culpa do causador do dano".

\section{Justificativa}

Entende-se necessária a consagração da culpa presumida, pela dificuldade em que se encontra, geralmente, a vítima de fazer a prova direta da culpa.

\section{Proposição}

Alterar e aditar o art. 180: "Invalidado o negócio jurídico restituir-se-ão as partes e terceiros ao estado em que antes dele se achavam, e, não sendo possível restituí-los, serão indenizados com o equivalente.

Parágrafo único. Pelo valor da indenização que the couber em face do contraente beneficiado pelo reconhecimento da invalidade (art. 184), o terceiro de boa-fé poderá exercer o direito de retenção".

\section{Justificativa}

Procura-se, com a sugestão, tornar indene o terceiro, que poderia sofrer, de modo reflexo, os efeitos da invalidade. 


\section{6. ' Proposição}

Estender a rgra do art. 188 aos cascos de decadência, tendo em vista, principalmente, as hipóteses de anulabilidade, dando-se a seguinte redação ao art. 206: "Aplica-se à decadência o disposto nos artigos 188, 193 e 196, I".

\section{Justificativa}

Tem-se em mira abranger as hipóteses de decadência do direito e de proteção ao incapaz, em face de prazo extintivo.

Deliberou também a Comissão expressar aplauso ao restabelecimento do instituto da lesão, às inovações do art. 165, inciso 111 e 166, relativos às nulidades, à distinção explicita entre prescrição e decadência, ao art. 188, relativo à prescrição de exceção, ao art. 192, em face do art. 219, $\S 5 .^{\circ}$ do Código de Processo Civil, ao art. 200, relativo à interrupção de prescrição, e aos artigos 229 e 230, relativos às hipóteses de recusa a exame médico.

\section{Comissão}

(Direito das Obrigações)

\section{1. ' Proposição}

Retirar do Projeto o Capítulo XXII do Título VI do Livro I (artigos 866 a 889).

Retirar do Projeto o Capítulo XXII do Título VI do Livro I (artigos 866 a 889).

\section{Justificativa}

Os contratos bancários devem ser tratados em lei especial.

\section{2." Proposição}

Dar ao art. 517, em sua parte final, a seguinte redação: " . . caberá ao expropriado, ou aos seus herdeiros, direito de preferência pelo preço atual da coisa".

Em conseqüência, o artigo seguinte passará a ter esta redação:

Art. 518: "O direito de preferência não se pode ceder nem passa aos herdeiros, ressalvado o disposto no artigo anterior".

\section{Justificativa}

Convém que se dê ao art. 517 uma redação que se concilie com a atual jurisprudência do S.T.F., acerca da transmissibilidade causa-mortis do direito de preferência não convencional. 


\section{Proposição}

O Código deverá conter todos os preceitos gerais relativos aos vários títulos de crédito, que incidiriam, caso a caso, no que coubesse, deixando-se para as leis extravagantes apenas a regulamentação dos aspectos particulares dos diversos títulos.

\section{Uustificativa}

Mantém-se ainda fora do texto do Projeto diversas normas relativas à matéria e de igual cunho genérico, como aquelas pertinentes ao aceite, à multiplicação dos títulos e a vários outros institutos.

\section{4.` Proposição}

Dar ao $\S 3 .^{\circ}$ do art. 197 a seguinte redação:

"Intentada a ação contra o segurado, denunciará este a lide ao segurador, quando e como the determinarem as leis do proecsso".

\section{Justificativa}

O aludido parágrafo deve ficar em harmonia, com o disposto no artigo 70, inciso III, do Código de Processo Civil.

Foi aprovada a proposta, com a ressalva do Desembargador ARY FLORENCIO GUIMARAES, que expendeu o ponto de vista de que a matéria é de índole nimiamente processual, não se devendo criar, na lei civil, mais um caso de denunciação da lide.

\section{5.` Proposição}

Dar ao art. 934 a seguinte redação:

"O aval deve ser dado no próprio título".

\section{Justificativa}

A expressão "verso e anverso do" afigura-se inútil.

\section{6." Proposição}

Dar a seguinte redação ao parágrafo único do art. 462:

"O contrato preliminar deverá ser levado a registro para operar seus efeitos a respeito de terceiros".

\section{Justificativa}

A redação atual poderá levar ao entendimento de que, em qualquer caso, o registro será sempre indispensável. 


\section{7.a Proposição}

Suprimir o parágrafo único do art. 455.

\section{Justificativa}

A norma projetada é heterotópica, eis que é de exclusiva na. tureza processual, inteiramente disciplinada pelo atual C.P.C.

\section{3. ' Comissão}

(Atividade Negocial).

\section{1. ${ }^{a}$ Proposição}

Propõe-se, para o título do Livro II do Projeto, a expressão Da Atividade Mercantil, em substituição à constantes: Da Atividade Negocial.

\section{Justificativa}

Considera-se inexpressivo e de acepção ampla o neologismo "negocial".

A proposição foi aprovada, no Plenário, com restrições feitas pelos Desembargadores YOUNG DA COSTA MANSO e BRUNO AFONSO DE ANDRE, que optavam pela nomenclatura atual.

\section{2." Proposição}

Expungir do Projeto toda a parte referente à Atividade Negocial.

\section{Justificativa}

A inclusão da disciplina, não atende quer a considerações de ordem filosófica, quer a motivações de política legislatliva ou, simplesmente, de natureza pragmática.

Além disso, os institutos que regulam a atividade mercantil estão sujeitos a uma constante evolução, e por isso demandam tratamento através de leis especiais.

\section{3.' Proposição}

Retirar do Projeto o Capítulo XXII, Livro I (artigos 866 a 889).

\section{Justificativa}

Os contratos bancários devem ser objeto de disciplina em lei especial.

\section{4.a Proposição}

Dar nova redação à parte final do parágrafo único do artigo 1.003 , a fim de torná-la mais clara. 


\section{Justificativa}

Oo anteprojeto havia adotado redação mais consentânea com a definição objetivada.

\section{5." Proposição}

Alterar o nomen iuris de "sociedade em comum", como título do Capítulo I, do Subtítulo I, do Livro II do Projeto.

\section{Justificativa}

Parece mais apropriado o título "sociedade com patrimônio comum", de vez que "os bens e dívidas sociais constituem patrimônio especial, de que os sócios são titulares em comum" (art. 1.025 do Projeto).

\section{6." Proposição}

O texto do futuro Código Civil, no tocante às sociedades, não deve vincular-se a uma posição radical quanto à natureza jurídica do correspondente ato constitutivo.

\section{Justificativa}

Existe ampla controvérsia sobre a matéria.

\section{7." Proposição}

Reexaminar o texto do artigo 1.011, para que seja feita uma distinção bem clara entre a situação do menor e a do interdito.

\section{8. ${ }^{a}$ Propsição}

Reexaminar as remissões feitas da aplicação de normas das sociedades simples aos demais tipos societários, adotando-se uma dis posição unificada (artigos 1.07?, 1.081, 1.090 e 1.121 do Proj’ło).

\section{9.` Proposição}

Em face da retirada do Capítulo referente à sociedade anônima, do Projeto, recomendar que o concernente à liquidação das sociedades (artigos 1.136 a 1.146) seja colocado em seguimento à parte que disciplina a dissolução das sociedades (artigos 1.070 a 1.075).

\section{0.' Proposição}

Retirar o vocábulo "silvicola" art. 1.007.

\section{Justificativa}

O dispositivo não se coaduna com a acepção dada pelo art. $3 .^{\circ}$, item IV, além de ser desnecessário ao bom entendimento do texto. 


\section{Proposição}

Dar nova redação ao item II do art. 1.007, a seguir: "o pequeno empresário, considerados os seguintes elementos, isoladamente ou em conjunto".

\section{Justificativa}

Os elementos considerados são suficientes para a definição do pequeno empresário, não se fazendo necsssária a respectiva conceituação em decreto.

\section{2." Proposição}

Promover total reexame do Capítulo IV da Seção III, Título, IV, Livro II (arts 1.217 e seguinte), que trata de escrituração, reduzindo essa matéria aos preceitos fundamentais.

\section{3. ${ }^{a}$ Proposição}

Reformular o Capítulo VI do Título II, Subtítulo I (arts. I . 124 a 1.126), para, apenas, conceituar a sociedade em comandita por ações, tal como feito em relação à sociedade anônima.

\section{4. ${ }^{a}$ Proposição}

Substituir o título "Da Sociedade Limitada" para "Sociedade por Quotas de Responsabilidade Limitada" contido no Capítulo IV, do Subtítulo II, do Título II, alterando-se, nos textos pertinentes, a referida denominação.

\section{5. ' Proposição}

O Capítulo VII, referente à sociedade cooperativa, ficará restrito ao seguinte dispositivo: "A sociedade cooperativa reger-se-á por legislaçlão especial, aplicando-se-lhe, quando omissa, as disposições referentes à sociedade simples".

\section{6. a Proposição}

A Comissão sublinha a conveniência de a matéria referente às sociedades ligadas (arts. 1.131 a 1.135 do Projeto) ser examinada juntamente com os novos textos de projetos em andamento, pertinentes ao assunto.

\section{4." Comissão}

(Direito das Coisas)

\section{1. ' Proposição}

Incluir, onde couber, o seguinte artigo: "O proprietário, ou pos- 
suidor de um prédio, tem o direito de exigir do vizinho o cumprimento das normas de Direito Público relatlivas à vizinhança, à natureza da utilização e à localização dos imóveis, bem como das que preservem da polvição o ar e as águas e da destruição a flora, a fauna, a paisagem e as belezas naturais".

\section{Justificativa}

Essa norma, que havia sido sugerida pelo Des. EBERT CHAMOUN, é corolário indispensável à atuação do princípio do artigo $1.266, \S 1 .^{\circ}$.

\section{2." Proposição}

Alterar a redação do artigo 1.303, que passaria à seguinte: "Feiła por quem não seja proprietário, a tradição não alheia a propriedade, exceto se a coisa for transferida em circunstâncias tais que, ao adquirente de boa-fé, como a qualquer pessoa, o alienante se afigurar dono", assim como a inclusão de um parágrafo com a seguinte redação: "§ - Em se tratando, porém, de coisa furtada, a tradição não alheará a propriedade, devendo, no entanto, o prołrietário pagar ao possuidor o preço por que a comprou, se a aquisição se deu em leilão público ou em estabelecimento comercial".

\section{Justificativa}

Considerou a Comissão conveniente ampliar a proteção ao adquirente de boa-fé, além da hipótese da aquisição em leilão ou estabelecimento comercial. Pretendeu também manter a exceção tradicional na matéria, consagrada no artigo 521 do Código Civil.

\section{3.` Proposição}

Suprimir o artigo 1.508 e seu parágrafo, que reproduziram o artigo 813 e seu parágrafo do Código Civil, dizendo: "Salvo o caso de insolvência do devedor, o credor da segunda hipoteca, embora vencida, não poderá executar o imóvel antes de vencida a primeira. Parágrafo único. Não se considera insolvente o devedor, por falta ao pagamento das obrigações garantidas por hipotecas, posteriores à primeira".

Aprovou, ainda, a Comissão a supressão do inciso VI do artigo 1.530 (reprodução do atual 849, VII) que previa a arrematação ou adjudicação como modo de extinção da hipoteca e, enfim, recomendou que o artigo 1.532 tivesse a seguinte redação: "Não será válida a venda judicial de imóveis gravados por hipotecas devidamente inscritas, sem que tenham sido notificados judicialmente os respectivos credores hipotecários que não forem de qualquer modo par- 
tes na execução, a fim de que possam exercer direito de preferência no prazo de trinta dias; caso não o exerçam, a venda judicial não extinguirá as hipotecas".

\section{Justificativa}

A Comissão entendeu que, mantida em todo o seu rigor a realidade da hipoteca, não deverão subordinar-se as execuções ao seu vencimento.

Também se considerou que, na hipótese de insolvência, o vencimento antecipado de todos os créditos impunha solução específica, que não cabia disciplinar dentro do instituto da hipoteca.

\section{4. ${ }^{\circ}$ Proposição}

Dar a seguinte redação ao $\S 2 .^{\circ}$ do art. 1.249: "Não obsta à manutenção ou reintegração na posse a alegação de propriedade, ou de direito sobre a coisa. Será, porém, deferida a posse a quem evidentemente tiver a propriedade, se, com base nesta, for ela disputada".

\section{Justificativa}

A Comissão pareceu que a inclusão da exceptio proprietatis, formulada nos termos da Súmula 487 do Egrégio Supremo Tribunal Federal, corrigia os defeitos de redação do art. 505 do Código Civil.

O Professor SIMÃO ISAAC BENJÓ, no Plenário, se opôs a esta proposição, por entender que deveria manter-se a redação do $\S 2 .^{\circ}$ do art. 1.249 do Projeto, separando-se, de modo concludente, ० processo possessório do petitório.

\section{Apoiou-o o Desembargador BRUNO AFONSO DE ANDRE.}

Tendo-se procedido à votação, foi aprovada a proposição, contra 9 (nove) votos, com uma abstenção.

\section{5.ं Proposição}

Dar ao art. 1.260 a seguinte redação: "O reivindicante obrigado a indenizar as benfeitorias tem o direito de optar entre o seu valor atual e o seu custo, quando se tratar de possuidor de má fé; tratando-se de possuidor de boa-fé, a indenização será sempre pelo valor atual".

\section{6." Proposição}

Excluir do Projeto o instituto da anticrese, em face dos fundamentos expostos pelo Desembargador EBERT CHAMOUN, em sua exposição de motivos. 


\section{Comissão}

(Direito de Família)

\section{Proposição}

Suprimir 0 art. 1.543.

\section{Justificativa}

Entendeu a Comissão que o dispositivo é obscuro, nada explicando a assertiva de tratar-se de direito absoluto, sob cujo conteúdo caberá ao juiz construir.

\section{2." Proposição}

Tornar explícitas as disposições que baralham o casamento religioso precedido de habilitação do que não o seja.

Em conseqüência:

a) dar a seguinte redação ao art. 1.546:

"E obrigatório o registro civil do casamento religioso, precedido de habilitação feita nas condições de lei, de vendo providenciá-lo o celebrante, para esse feito equiparado a funcionário público, ou qualquer dos cônjuges";

b) substituir a redação do atual $\S 1 .^{\circ}$ do art. 1.546 pela seguinte:

"Na hipótese de falecimento de qualquer dos cônjuges, o registro civil do casamento religioso, precedido de habilitação na forma da lei, poderá ser promovido por seus descendentes ou ascendentes";

c) observar, no $\S 2 .^{\circ}$ do art. 1.546 , a seguinte redação:

"Será ineficaz o registro civil de casamento religioso se anteriormente à sua celebração qualquer dos consorciados se anteriormente à sua celebração qualquer dos consorciados, houver contraído com outrem matrimônio civil".

"Efetuado o casamento religioso, com prévia habilitação civil, esta não perderá eficácia para os efeitos de futuro registro do casamento";

e) transformar em disposição autônoma, que passaria a ser $\circ$ art. 1.547, o atual § $3 .^{\circ}$ do art. 1.546;

f) alterar 0 item IX do art. 1.552, que viria a ter a seguinte redação: 
"Art. 1.552

IX. A pessoa que tenha contraído matrimônio religioso precedido de habilitação, nos termos da lei civil, ainda que não requerida a inscrição desse casamento no registro civil".

\section{3. ' Proposição}

Suprimir a parte final do art. 1.550.

\section{Justificativa}

A recorribilidade das decisões é princípio firmado na sistemática processual, tornando-se, pois, dispensável a manutenção da parte final do dispositivo, que prevê "recurso para instância superior".

\section{4.' Proposição}

Suprimir o item VIII do art. 1.552.

\section{Justificativa}

Trata-se de reiteração do impedimento do art. 183, VII, do Código de 1916, de cuja aplicação não se tem conhecimento.

O impedimento matrimonial assim configurado força a manutenção do concubinato entre os adúlteros, mesmo depois da morte do cônjuge enganado.

\section{5. ' Proposição}

Excluir do art. 1.588 a expressão "pelos herdeiros".

\section{Justificativa}

Uma vez que o Projeto inclui, dentre os herdeiros, os colaterais até $\circ 4 .^{\circ}$ grau, poderiam eles agir sob a inspiração quase exclusiva de interesses pecuniários.

\section{6." Proposição}

Rever o art. 1595, para resguardar a condição de legítimo, do filho nascido de matrimônio nulo ou anulável, independentemente da perquirição da boa fé unilateral ou recíproca dos côjuges.

\section{Justificativa}

Trata-se de tendência que se manifesta nas legislações mais atualizadas Código Civil espanhol, art. 69; Código Civil português, art. 1.802; Código Civil suíço, art. 133, I). 


\section{7.' Proposição}

Integrar em um só os arts. 1.609 e 1.610, com aditamento de mais uma hipótese de desquite, mantido o parágrafo único do art. 1.609 .

O art. 1.609 passaria a ter a seguinte redação "qualquer dos cônjuges poderá propor ação de desquite, ocorrendo algum dos seguintes motivos:

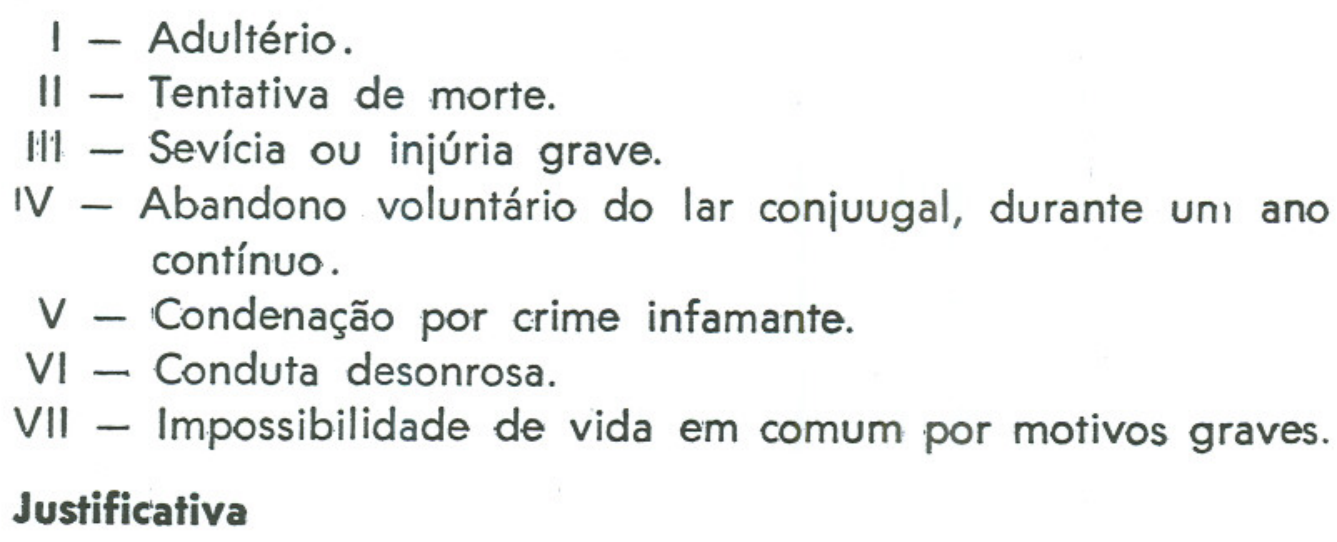

Os casos especificados nem sempre importam impossibilidade de vida em comum, e esta pode ocorrer sem que se verifique qualquer daqueles, conforme anterior jurisprudência, sob a escoteira sustentação do saudoso Min. PHILADELPHO DE AZEVEDO.

\section{8." Proposição}

Modificar o art. 1.615, que passaria à seguinte redação:

"A mulher condenada na ação de desquite perde o direito a usar o nome do marido. Se condenado o marido, ou se nada se dispuser no desquite por mútuo consentimento, assiste à mulher o direito de retomar seu nome de solteira".

\section{Justifidativa}

Pareceu à Comissão muito boa a ressalva constante da segunda parte do art. 1.615 do Projeto.

Sugere, no entanto, que se assegure igual faculdade à mulher, quando nada a respeito se dispuser no desquite por mútuo consentimento.

\section{9.ं Proposição}

Dar a seguinte redação ao art. 1.763:

"O cônjuge desquitado perde o direito a alimentos se viver em concubinato, ou tiver procedrimento indigno". 


\section{Justificativa}

A Comissão sugere que $\circ$ cônjuge não possa recuperar $\circ$ direito de reclamar alimentos, uma vez rompido o concubinato ou cessado o procedimento indigno, esteada nos fundamentos aduzidos pelo Prof. SIMÃO ISA.AC BENJÓ ("Aspectos da Obrigação Alimentar", in "Revista de Direito da Procuradoria Geral Ida Justiça", vol. I, pág. 36).

O Des. BASILEU RIBEIRO FILHO sugeriu, no Plenário, que se conservasse a redação do art. 1.763 do Projeto, por representar evolução da doutrina.

Deixa-se-ia a critério do juiz o restabelecimento da pensão alimentícia.

Contrariou tais argumentos o Prof. SIMÃO ISAAC BENJÓ, que defendeu o ponto de vista da Comissão.

Passando à votação, foi aprovada a proposição, contra três (3) votos.

\section{0." Proposição}

Alterar a redação do art. 1.654, para manter o disposto na Lei n. ${ }^{\circ}$ 5.582/70, que alterou o art. 16 do Decreto-lei n. ${ }^{\circ} 3.200 / 41$.

\section{Justificativa}

A decisão judicial somente é necessária, à falta de acordo, se advier prejuízo ao menor que estiver sob o poder da mãe.

\section{1." Proposição}

Dar a seguinte redação ao art. 1.603 e seu parágrafo: "Art. 1.603. A direção da sociedade conjugal cabe ao marido, em conjunto com a mulher, sempre no interesse do casal e dos filhos.

Parágrafo único. As questões essenciais serão decididas em comum. Havendo divergência, poderão os cônjuges recorrer à autoridade do juiz, em conjunto ou separadamente".

\section{Justificativa}

Deve-se observar o princípio de igualdade jurídica entre o homem e a mulher.

\section{2." Proposição}

Dar a seguinte redação ao art. 1.621:

"O paí, ou a mãe, que contrair novas núpcias não perde 
- direito de ter consigo os filhos do leito anterior, que só lhe poderão ser retirados, por ordem judicial, provado que qualquer deles, o padrastro ou a madrastra não os tratam convenientemente".

\section{Justificativa}

O art. 1.621 é unilateral porque só dispõe sobre a mãe.

Igual solução deve-se dar à hipótese do pai que venha a contrair novas núpcias.

\section{3.a Proposição}

Alterar, no parágrafo único do art. 1.609, a palavra "representado" para "substituído".

\section{Justificativa}

A possibilidade de ser a ação de desquite proposta por ascendente ou irmão do cônjuge, incapaz de exercê-la, configura uma hipótese de substituição processual.

Corrige-se, assim, o equívoco do Código de 1916 (art. 316, parágrafo unico).

\section{Proposição}

Transformar os arts. 1.694 e 1.695 em um só dispositivo legal, de n. ${ }^{\circ}$ 1.694. com o parágrafo único correspondente ao art. 1.695.

Seria dada ao art. 1.695 a mesma redação do art. 240 do Código Civil de 1916.

\section{Justificativa}

A Comissão verificou que o Projeto não cuidou expressamente da imulabilidade do regime de bens, parecendo-lhe conveniente estabelecê-la.

\section{Proprosição}

Suprimir a parte final do art. 1.696, com dois pontos na palavra casamento.

\section{Justificativa}

Entende a Comissão que, no regime da separação obrigatória, deve prevalecer a comunicação dos aqüestos (Súmula 377), a despeito da doutrina, que está divorciada da realidade. 


\section{6." Proposição}

Suprimir o $\S 3 .^{\circ}$ do art. 1.669 e retificar o erro material da parte final do art. 1.672, que se refere, em verdade, ao art. 1.886.

\section{Justificativa}

A Comissão recomenda sejam levados em consideração os comentários feitos pelo Des. BULHÕES DE CA.RVALHO em sua obra "Emendas ao Projeto 643 do Novo Código Civil", págs. 81 a 96, no sentido de melhorar o tratamento legislativo do instituto, especialmente em referência à supresão ora proposta.

\section{6." Comissão}

(Direito das Sucessões)

\section{1.' Proposição}

Excluir o Capítulo $\mathrm{X}$ do Títu'o III - Livro $\mathrm{V}$, referente à deserdação.

\section{Justificativa}

Trata-se de instituto odioso, cujas finalidades iá estão preenchidas no Capítulo V, arts. 1.861 a 1.865 do Título I.

\section{2." Proposição}

Na hipótese de ser mantida a deserdação, acrescentar ao art. 2.011 a expressão:

"...observada a regra do art. 1.963 e seu parágrafo único".

O artigo passaria pois, a ter a seguinte redação:

"Os herdeiros necessários podem ser privados de sua legítima, ou deserdados, em todos os casos em que podem ser excluídos da sucessão, observada a regra do art. 1.863 e seu parágrafo único".

\section{Justificativa}

Evita-se a dúvida, em face da redação atual do artigo, tornando claro que o deserdado não terá dieito ao usufruto ou à administração dos bens que aos seus sucessores coubemrem na heranrça.

\section{3.` Proposição}

Se se mantiver a deserdação, acrescentar, outrossim. ao art. . . 2.014 a expressão:

". . judicialmente reconhecida". 


\section{Justificativa}

O acréscimo visa a evitar dúvida quanto à necessidade, sempre, da sentença declaratória da deserdação.

\section{4." Proposição}

Substituir no parágrafo único do art. 1873 a expressão "da introdução" por "do ajuizamento".

\section{Justifićativa}

Teve-se o escopo de dar mais precisão ao parágrafo.

No Plenário, o Relator Geral indagou do Relator da 6. Comissão qual o critério adotado para se preferir "ajuizamento da lide" a "propositurar da ação", em consonância com o art. 263 do Código de Processo Civil.

O Des. ARY FLORENCIO GUIMARÃES defendeu a propriedade da segunda expressão, que mereceu, também, o assentimento dos membros da referida Comissão.

Passaria, pois, o parágrafo único do art. 1.873 a ter a seguinte redação:

"A partir da propositura da ação, a responsabilidade do possuidor se há de aferir pelas regras concernentes à posse de má fé e à mora".

\section{Proposição}

Dar esta redação ao art. 1.899 e seu parágrafo único:

"Art. 1.899. Pode o testador estabelecer cláusula de inalienabilidade, incomunicabilidade ou impenhorabilidade quanto à legítima. ou a conversão dos bens que a constituem em outros de outra espécie.

Parágrafo único. Não havendo motivo justo, pode a cláusula ser invalidada por sentença provocada pelo herdeiro".

\section{Justificativa}

Objetiva-se. com a alteração, evitar constrangimento ao testador ou aos seus parentes próximos, em torno do motivo determinante da cláusula e, simultaneamente, possibilitar ao interessado a oportunidade de demonstrar a sem-razão do vínculo estabelecido. 


\section{6." Proposição}

Suprimir o requisito constante da parte final do art. 1.879:

". . se for ascendente dos herdeiros com que concorrer". Suprimir, também, em conseqüência, o art. 1.880 .

\section{Justificativa}

Pretende-se, com isso, afastar a distinção que surge no artigo 1.880, em relação a filhos legítimos e ilegítimos.

\section{7. ${ }^{a}$ Proposição}

Substituir, no art. 1.885, a palavra "legítimos" por "ilegítimos".

\section{Justificativa}

Busca-se harmonizar o texto com a sistemática do Projeto e com a legislação vigente.

\section{8. ' Proposição}

Dar a seguinte redação ao parágrafo único do art. 1.886: "Em se tratando de adoção restrita, se o adotado deixar descendentes legítimos ou ilegítimos, ascendentes ou cônjuge, o adotante não será chamado à sucessão".

\section{Justificativa}

Pretende-se, com a alteração proposta, atribuir ao adotando o mesmo tratamento que se dispensa ao adotado no art. 1.885.

\section{9.' Proposição}

Dar a redação a seguir ao parágrafo único do art. 2.078: "Extingue-se em 2 (dois) anos o direito de anular a partilha (art. 169)".

\section{Justificativa}

Ampliou-se o prazo, que passa a coincidir com o da ação rescisória, e se fez remissão ao art. 169, para evitar dúvida quanto à nulidade absoluta.

\section{0.` Proposição}

Transformar em $\S 1 .^{\circ} \circ$ atual parágrafo único do art. $2.037 \mathrm{e}$ acrescentar um $\S 2 .^{\circ}$, com a seguinte redação:

"§ 2.․ No caso de as dívidas absorverem todo o acervo, o prêmio será arbitrado pelo juiz, consoante aprecia- 
ção equitativa, e o seu quantum sairá do monte, como despesas judiciais".

\section{Justificativa}

Resguarda-se, assim, o princípio de que o trabalho deve ser remunerado, tanto mais quanto indispensável.

\section{1..' Proposição}

Acrescentar o seguinte inciso ao art. 1.876:

". aos Estados, ao Distrito Federal e à União".

\section{Justificativa}

É o que já consta do Código vigente e se impõe que continue, uma vez que, a título de sucessor e com causa fundamental da morte do autor da herança, é que ela se transmite a qualquer daquelas entidades.

\section{2." Proposição}

Suprimir o art. 2.098 .

\section{Justificativa}

Esta proposição é conseqüência da mudança de redação sugerida para o art. 1.899, com a exclusão, com a exclusão do requisito "justa causa".

\section{CONCLUSÃO}

Quando o Simpósio atinge seu termo, é possível, ao fazer um balanço das realizações ocorridas no augusto qüinquiídio em que se desenrolou, depreender a excelência dos resultados, que devarão influir, certamente, no processo de elaboração legislativa do novo Código Civil.

Por derradeiro, agradecemos a grande honra que nos foi conferida pela predara Diretoria da Associação dos Magistrados Brasileiros, escolhendo-nos para a elaboração do relatório geral dos trabalhos.

Rio de Janeiro, 5 de dezembro de 1975. 